Marlena Wanda Stradomska

Maria Curie-Sklodowska University, Poland. Lublin

DOI: $10.13166 / \mathrm{JMS} / 130706$

JOURNAL OF MODERN

stradomskamarlena@onet.pl

ORCID iD: https://orcid.org/0000-0002-2294-856X

SCIENCE TOM 2/45/2020,

S. $43-62$

KHRYSTYNA BIDONKO

Maria Curie-Sklodowska University, Poland. Lublin

bidonko.khrystyna@gmail.com

\title{
AdDiction IN THE AGE OF INTERNET THE CASE OF E-DRUGS
}

\begin{abstract}
The subject of the article are reflections on the issue of addiction in the $21^{\text {st }}$ century as exemplified in e-drugs. This is a relatively new type of threat. It affects young people who often use the Internet and are permanently online. E-drugs gained particular popularity in 2008-2010. The people who are currently in the 20-30 age range could be exposed to these resources at that time. Therefore, it was decided to determine what is the level of knowledge about e-drugs among young people in Poland, what are the experiences of the respondents regarding the use of psychoactive substances. The research was carried out using the author's survey, which was made available through an interactive Google survey. The responses of 102 respondents were included in the final analysis, including 54 men and 48 women $(M=22,3)$ living in the Lubelskie Voivodeship. More than half (53\%) visited websites where they could use e-drugs, $43 \%$ have used them, including $20 \%$ more than once. E-drugs are considered the least dangerous in terms of the possibility of addiction, compared to other types. The average value given to e-drugs is 7.3 out of 12 . On the other hand, alcohol (9), heroin (8.3), gambling (8.3) and computer games (8.3) were considered the most dangerous measures. This work has a theoretical and practical dimension. In addition to theories independent author's research and subsequent practical implications are presented.
\end{abstract}

KEYWORDS: Internet, threat, addiction, e-drugs, generation $Z$ 


\section{INTRODUCTION}

The development of technology in the last century has undoubtedly contributed to the improvement of the living conditions of humanity, but new technologies can also be dangerous (Stradomska, 2019). Platforms on the Internet, in particular social media, can lead to addiction in at least several ways. Within the behavioural mechanism of addiction, for example, the gaming disorder highlighted in ICD-11 develops. Another threat is the illegal market for prohibited substances that exists on the network (WiszejkoWierzbicka, Kidawa, Jabłońska, 2016).

Mention should also be made of the non-medical use of medicines whose over-the-counter sales are available online. On the other hand, users can look for alternatives to 'traditional' drugs. The example of this substitute are e-drugs, which are the subject of this work.

People born between 1995 and 2012, commonly referred to as the Z-generation, are particularly vulnerable to these Internet-related threats (Singh, 2014). The distinguishing feature of this generation is the high fluidity of using electronic devices (telephone, tablet, computer) and the Internet, which naturally results from the fact that access to these resources is widespread. The characteristic feature of the $\mathrm{Z}$ generation is a compulsive usage of social media, resulting in a number of new phenomena, for example "facebookmania" (Runcan, 2015) or phonoholism (Jarczyńska, Orzechowska, 2014). This means that the mentioned generation is particularly vulnerable to the dangers of the Internet or difficulties of an inter and intrapersonal nature (Stradomska, Wolińska, Marczak, 2016; Stradomska, 2019).

Considering that representatives of generation $\mathrm{Z}$ are at risk of using danger substances, it was decided to determine whether young people in Poland really have knowledge about virtual drugs, and whether they have ever been subjected to these drugs.

\section{E - DRUGS}

In 2008-2010, so-called "e-drugs" reached their peak of popularity (at least in the mass media). These resources were particularly popular in the years 2009-2010 among young people, for example in Russia (Леонидович, Есаков, Назарова, 2014). 
Information from online forums that were available at the time of the greatest popularity of e-drugs suggests that sound files of this type were used to achieve states similar to those caused by some psychodelic drugs. In connection with the above, corresponding file names appeared: "LSD" or "marijuana" (https://hyperreal.info/talk/doser-t12837.html)

E-drugs, audio drugs or i-dosers stand for audio files based on binaural beats. The technology is based on the following action - a person listens to sinusoidal sound waves in the near range, for better efficiency through headphones. The difference between sound waves is recorded and analyzed in the brain. At the same time, the range of sounds heard by people is about $15-20,000 \mathrm{~Hz}$, and the difference between the waves used in the research may be smaller than the lower level of heard sounds.

The phenomenon of perception of beating was discovered in 1839 by Heinrich Dove. Since then, research has been conducted on this topic, especially in the context of possible therapeutic effects (Motyka, 2015).

Significantly later, in the 2000 s, sound files gained popularity on the Internet with a non-therapeutic application. In thematic forums, binaural beats are called "legal drugs" and used to achieve state of euforia. On numerous public websites, including Spotify, Youtube, Soundcloud. There are sound files that are intended for relaxation or improvement of cognitive processes, including memory. In addition, on the hemisync website - files are offered to help get rid of addiction, detoxify the body, and increase life energy. The cited effects are only part of the benefits of 'e-drugs' on the internet. In addition, there are websites for generating your own beatings (https://mynoise.net/NoiseMachines/ binauralBrainwaveGenerator.php)

The subject of e-drugs is characterized by some fluctuations in popularity. After the mentioned increase in popularity - interest decreased, and then appeared in a completely different aspect. More and more research on binaural beats associates them with meditation and regaining a state of relaxation (Motyka 2015). The renewed interest in binaural beats can be linked to the growing popularity of yoga, meditation, relaxation and mindfulness (Sas, Chopra, 2015). 


\section{The POTENTIAL HARMFULNESS OF E-DRUGS}

Considering the cited data, the question arises whether e-drugs can be harmful. The question seems to be rhetorical, given that users become convinced that listening to sounds will increase their sexual and intellectual performance, or allow them to improve their lives in general terms. One of the distributors, I-Doser, argues that the so-called doses are harmless, but they put you in a state similar to orgasm, intoxication with marijuana or other chemicals. In addition, the manufacturer states on its website that it does not guarantee the effectiveness of the distributed resources and is not responsible for adverse effects. Users should be aware that they use the material at their own risk and for entertainment purposes only.

An interesting aspect is also the fact that both positive and negative effects of using binaural beats are declared, although there is definitely less information about the last. The impact of e-drugs (including the harmful one) is not properly confirmed. Research by Reedijk, Bolders and Hommel (2013) showed that the beatings do not affect convergence thinking, although for some participants there has been an improvement in the performance of tasks requiring divergent thinking, i.e. the one associated with seeking many opportunities to solve a given problem. It turned out that indirectly binaural beats can increase the level of neurotransmitters - it being an effective method in strengthening creative thinking similar to the didactic method which is "brainstorming" At the same time, in other people, the same sound stimuli can degrade performance in these types of tasks. In turn, Le Scouarnec, Poirier, Owens, Gauthier, Taylor and Foresman (2001) have shown that listening to beating beats can be beneficial in reducing mild anxiety disorder.

Despite the possible benefits, the use of beats is not recommended for children (up to 18 years of age), beats used for a long time also cause a possible negative effect on the nervous system. On the other hand, experiencing several types of waves at the same time may negatively affect the cardiovascular system (Bhatia, Rasal, Shelar and Mulik, 2016). Similar results were obtained in other studies - the impact of binaural beats is not entirely predicted, because it depends both on the frequency of the sound and the individual conditions of a person. 
On the other hand, people researching the subject indicate other danger. Users who reach for electronic substitution of addictive substances are more susceptible to the use of chemical substances in everyday life (TuszyńskaBogucka, Kwiatkowski, 2015). In addition, they are more likely to become addicted to 'real' drugs. If the i-dosers experiment is not successful, they may be looking for alternatives that will be more noticeable and consequently harmful. Lack of stimulation may cause that the body will not be able to function without stimulation.

Opinions on thematic forums included, among others, the following: "Different beats are not as powerful and fun as real drugs, but they are not a bad way to spend time on a lazy weekend" (Asad, 2012). In other cases, people complain of headaches after listening session (e-drugs) and declare disappointment with electronic drugs (https://hyperreal.info/talk/ doser-t12837.html)

It is difficult to find reliable medical research confirming the hypothesis that e-drugs cause addiction. Other substances such as alcohol, cigarettes and other plant-derived drugs are widely available and known. However, there are more and more references to this form of spending leisure time. The topic of e-beating is becoming an issue among youth and young adults, and is available on online forums or groups designed to share experiences through social media. In addition, sound stimuli are often exposed many times in studies using binaural beats, such as, for example, in the studies of Le Scouarnec and co-authors (2001), but these works do not mention the occurrence of addiction symptoms.

On the other hand, one can argue that a person may become addicted to the act of listening to beats through the behavioural addiction mechanism. It should then be assumed that a person addicted to binaural beats exhibits such behaviours as, for example:

- increasing the priority of listening so that it becomes more important than everyday activities and other interests;

- continuing and increasing the frequency of listening, despite the negative consequences associated with it;

- lack of control over the amount of time spent on action, inability to refrain from listening. 
- increasing the priority associated with stimulating and feeling the need to take a given substance or carry out activities,

- lack of efficiency in personal, professional or scientific life without stimulation with a given substance and others.

Nevertheless, confirmation or refutation of the above assumption requires a series of psychological and medical tests. At present, there is not sufficient empirical basis to conclude that binaural beats are drugs (Tuszyńska-Bogucka, Kwiatkowski, 2015).

\section{Methodology}

An original survey was conducted to obtain information on e-drugs. It is a first study in a series of studies on e-drugs. Its purpose was to recognize the level of knowledge among people in early adulthood on the subject and to provide an initial understanding of the relationships that may arise in the course of application of e-drugs. More information on the research procedure, hypotheses and the study group will be presented in the following sections.

In addition to surveys, structured interviews were conducted, due to the amount of material they will be presented in subsequent articles on e-drugs.

\section{The hypotheses}

The following hypotheses have been suggested for the study purpose.

1. Young people between 20 and 26 years old have knowledge of e-drugs.

2. Young people who use psychoactive substances can also become addicted to other substances.

3. Young people perceive e-drugs as less hazardous than other psychoactive substances.

4. Young people are aware of the dangers of using e-drugs.

Additional goals of the article are: introducing the topic of e-drugs, reviewing the literature on the subject, estimating the level of risk associated with e-drugs. 


\section{Research tool}

The research tool was prepared in an interactive Google Form. For the purposes of the study, an original survey consisting of four parts was constructed. In addition to data on their experiences with psychoactive substances, the respondents answered questions related to the phenomenon of addiction, described their experience with e-drugs and answered questions about addiction in a social context. The record part was also important, allowing for additional analyzes.

An interactive survey was conducted on a group of 200 people, however 102 people were included in the final analysis. The remaining respondents did not agree to use their answers for further analysis, which they informed via the form. Some of them claimed that they do not have knowledge about addiction or do not want to discuss the subject because of the fields of study or profession they are studying.

The project has been implemented since the beginning of the 2019/2020 academic year. The survey was conducted online, in the first quarter of 2020.

\section{Study group}

The survey was voluntary and kept the respondents anonymous. Finally 102 people participated in the study, including 54 men and 48 women $(\mathrm{M}=22.3)$. These are students of Lublin universities who were randomly invited to the study and gave voluntary consent to participate. Respondents study psychology, law, political science, pedagogy, as well as economics, mathematics, medicine and another sciences. In this way, the group can be considered representative of the student community of the city of Lublin. The questionnaire was made available by electronic and traditional means via the Internet and student information of individual universities.

Among the respondents, 64 declared that they smoked cigarettes, 88 ticked the yes (or yes, more than once -41 people) option in the question of using psychoactive substances other than alcohol and cigarettes. Of the mentioned substances, marijuana was mentioned most often (29 times), as well as amphetamine (11 times) and LSD (8 times). Cocaine, crack, and designer drugs were also among the most frequently mentioned. Other statements were devoid of the names of the means, but the respondents 
placed information: "something to focus", "depends on what I can afford", "I experiment a lot" or "nothing special". Subjects were also asked to indicate the frequency of alcoholic beverages consumption. A significant proportion (39 people) indicated that they drink alcohol 2-3 times a week. The detailed results are presented in diagram 1.

\section{How often do you drink alcoholic beverages?}

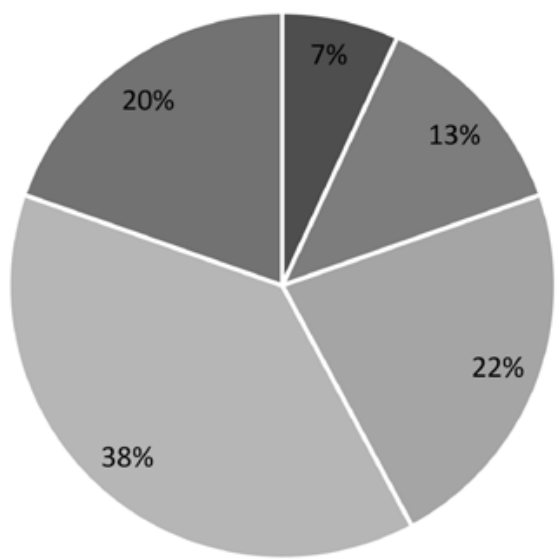

- Never

= Once per month

= 2-4 times per month

= 2-3 times per week

- More than 4 times per week

Diagram 1. Frequency of drinking alcohol by respondents

\section{Results}

In the first part of the study, participants declared their own level of knowledge about addiction. Almost half of the respondents (46\%) agreed with the statement "I have a good understanding of addiction", 30\% of respondents answered "I strongly agree", the rest answered "I do not know" or "I do not agree" (15\% and $9 \%$ respectively).

Respondents were also asked to provide a definition of the term 'addiction'. Due to the nature of the answers (open answer), they were categorized into several groups. Some responses referred to the concept of coercion, placing the locus of control concerning addiction outside. These include the following examples: "compulsion to do something or to accept a substance," "forcing a person to accept a substance." Other responses referred to the person's 
responsibility and sense of agency for taking the substance. There are also metaphorical responses having a negative connotation and neutral responses, stating e.g. the symptoms of addiction. The respondents also mentioned substances that one can be addicted to. The categories of the answers with numbers and examples are listed in the following table.

\section{Tab. 1. Definitions of the concept of "addiction" according to respondents}

\begin{tabular}{|c|c|l|}
\hline Category & $\begin{array}{c}\text { Amount } \\
\text { of answers }\end{array}$ & \multicolumn{1}{|c|}{ Examples of answers } \\
\hline Features of addiction & 26 & $\begin{array}{l}\text { Neglecting other things because of } \\
\text { alcohol, drugs }\end{array}$ \\
\hline Statements concerning addiction & 13 & Addiction can lead to death \\
\hline Other & 13 & A substance that makes people addicted \\
\hline $\begin{array}{c}\text { A psychologically correct or } \\
\text { similar definition }\end{array}$ & 11 & $\begin{array}{l}\text { A condition in which, despite being } \\
\text { aware of the harmfulness of performing } \\
\text { an activity, you are still performing it. } \\
\text { You know how you feel when you do it } \\
\text { or after it and you strive to achieve this } \\
\text { state, but you need more and more to } \\
\text { feel satisfaction. }\end{array}$ \\
\hline Coercion & 9 & Forcing a person to take a substance \\
\hline Negative metaphor & 8 & Vice \\
\hline Necessity & 7 & The need to consume some substance \\
\hline Type of addiction & 7 & $\begin{array}{l}\text { Behavioral addiction comparable to } \\
\text { e.g. sex or pornography addiction }\end{array}$ \\
\hline Lack of control & 4 & $\begin{array}{l}\text { Lack of control over the impulse } \\
\text { pushing to resort to an addictive agent }\end{array}$ \\
\hline A way to deal with problems & 2 & Detachment from problems \\
\hline
\end{tabular}

In order to check the declared level of knowledge in the topic regarding the issues undertaken, the respondents were asked to mark the answers that they think characterizes addiction. At least half of the respondents marked physiological and some behavioral manifestations of addiction. Particularly 
noteworthy, however, is that only $30 \%$ of respondents noted neglect of relationships with people by an addict.

The next part of the survey concerned issues which addictive agents are known to the respondents. E-drugs were selected by $60 \%$ of respondents. Then the respondents were asked to rank the substances (activities) according to the level of danger. The substances to which it is easiest to be addicted to are 1 , and those to which it is difficult to become addicted - 12. The table below presents the positions in the survey listed in order and the average value assigned to them by the study participants.

Tab. 2. Level of possible substance (activity) addiction

\begin{tabular}{|c|c|}
\hline Name & Average value assigned \\
\hline Alcohol & 9 \\
\hline Heroin & 8,3 \\
\hline Computer games & 8,3 \\
\hline Gambling & 8,3 \\
\hline Cocaine & 8 \\
\hline Nicotine & 7,9 \\
\hline Marihuana & 7,8 \\
\hline Shopping & 7,8 \\
\hline E-cigarrettes & 7,7 \\
\hline Masturbation & 7,6 \\
\hline Amfetamine & 7,6 \\
\hline E-drugs & 7,3 \\
\hline
\end{tabular}

According to the cited data, e-drugs are considered the least dangerous in the context of addiction. The average value given to e-drugs is 7.3 out of 12 possible. On the other hand, alcohol (9), heroin (8.3), gambling (8.3) and computer games (8.3) were considered the most dangerous agents.

The next part of the survey concerned strictly e-drugs. From the existing names of the phenomenon, the term "e-drugs" is known to 69 percent of respondents, "binaural beats" - 22\%, "binaural beats" - 17\%, "I-dosers" - 9\%, 
"audio drugs" - 8\%. Despite the knowledge of the term, some people do not know its meaning (24 answers), and some (14 answers) mistakenly believe that the term refers to a drug substitute, substances created in the image of e-cigarettes and other answers that do not match the actual state.

More than half (53\%) of them visited e-drug websites on the Internet, although $43 \%$ used them, including $20 \%$ more than once.

Despite the fact that in the previous part of the study, students pointed out that it is harder to get addicted to e-drugs than other substances, $65 \%$ of participants believe that e-drugs are in part as dangerous as "traditional" drugs. $30 \%$ of people marked "I don't know". Detailed results are given in the diagram 2.

\section{E-drugs are as dangerous as "traditional" drugs.}

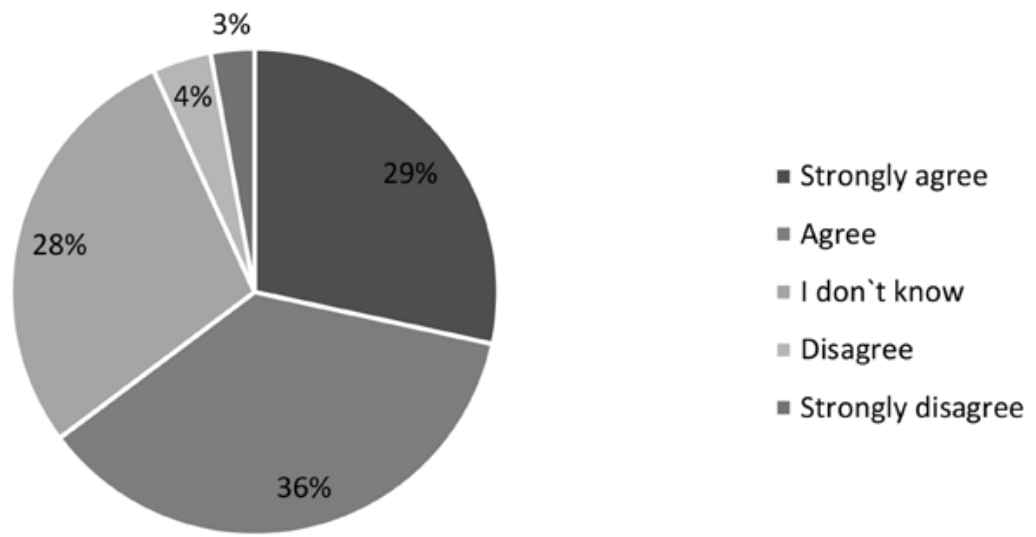

Diagram 2. The danger of e-drugs compared to traditional drugs

In the context of the fact that most respondents consider e-drugs to be dangerous, the following results are interesting. Above $73 \%$ of people would like to experience the impact of these substances. This answer corresponds to the answer to another survey item in the third and final part of the survey. The respondents were asked to comment on the statement which reads as follows: "I think it is worth experiencing the effects of drugs at least once in my life". Individual answers are given in the chart. 


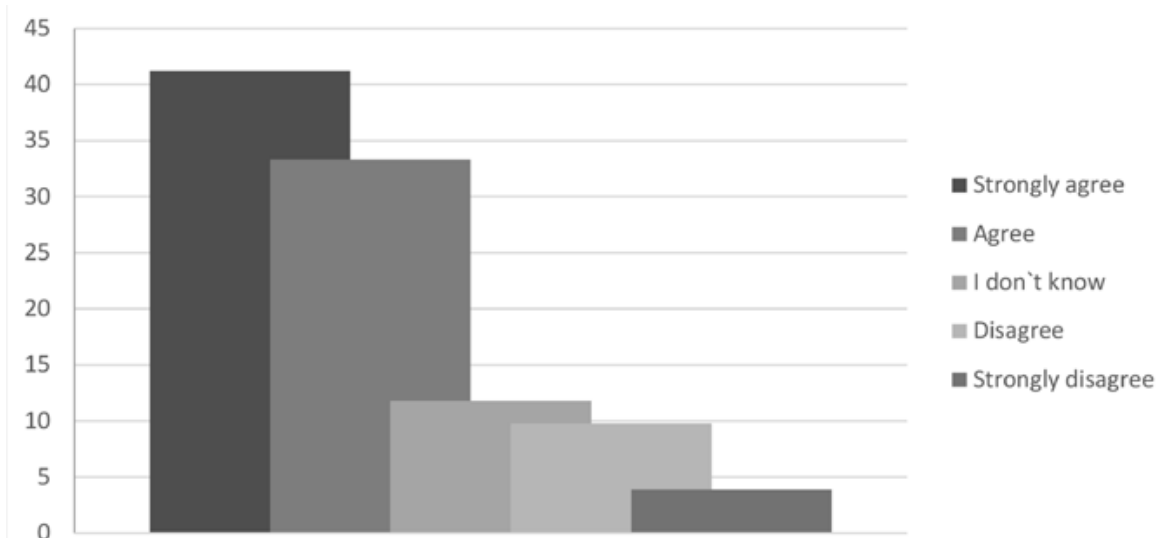

Chart 1. An answer to the question about whether it is worth experiencing the effects of e-drugs

On the other hand, study participants declare that they approach experiments with addictive substances in a cautious way. Only $5 \%$ of the respondents disagreed with the statement "I reveal ot to get addicted". Participants in the study also minding reveal that the problem of addiction would not happen to a loved one. In the statement "if I see that one of my relatives behaves risky (e.g., abuses alcohol), I warn the person about the possibility of addiction" 85\% of participants answered Agree (44\%) or Strongly agree $(36 \%)$. In addition, according to the declaration, similar behavior was practiced in the families of the subjects. $82 \%$ said that "when I was younger, my parents made sure that I knew about the dangers of addiction."

The survey highlights the broader social context of addiction. For example, respondents were asked if the problem of addiction was often raised in social discussion. A smaller proportion of respondents believe that the problem is not often raised in public (8.8\% answered Disagree, $2 \%$ answered Strongly disagree, some (7\%) answered I do not know. In addition, most respondents think that the problem of addiction is highly widespread in Poland, $88 \%$ of survey participants agree with the statement "Addiction in Polish society is a huge problem". 
One of the reasons for the high popularity of psychoactive substances is the large amount of publicly available ads, which $82 \%$ of respondents agree with (51\% Agree, 32\% Strongly agree, 7\% Disagree, 10\% I don't know). Advertising, however, is not the only reason for the popularity of the substances. Respondents were asked to choose three reasons why people reach for stimulants. The table below presents the answers of the respondents.

Tab 3. Reasons for using psychoactive substances

\begin{tabular}{|c|c|c|}
\hline Reason & Percentage & Amount of answers \\
\hline $\begin{array}{c}\text { Willing to experience something } \\
\text { new }\end{array}$ & $70,6 \%$ & 72 \\
\hline Willingness to break away from reality & $60,8 \%$ & 62 \\
\hline Desire to feel a momentary euphoria & $60,8 \%$ & 62 \\
\hline $\begin{array}{c}\text { Public opinion (e.g. popularity of a specific } \\
\text { substance) }\end{array}$ & $58,8 \%$ & 60 \\
\hline $\begin{array}{c}\text { The fact that drugs are prohibited and their } \\
\text { use is dangerous }\end{array}$ & $31,4 \%$ & 32 \\
\hline Availability of substances & $26,5 \%$ & 27 \\
\hline
\end{tabular}

I can spend time well (e. g. at a party) without any psychoactive substances

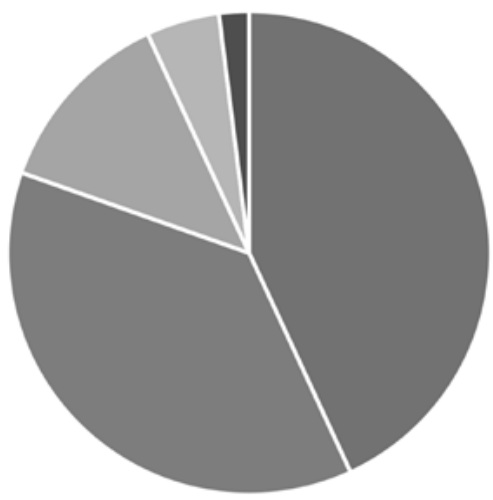

- Strongly agree " Agree " | | do not know " Disagree " Strongly disagree

Diagram 3. Attitude of the respondents to psychoactive substances 
According to the respondents' answers, the most common reason for using psychoactive substances is the desire to experience something new. The desire to detach from reality and try to feel momentary pleasure is also important. Most people agree that "moderate use of alcohol, tobacco or" light "drugs promotes relaxation and better integration in the group" (41\% Strongly agree, 40\% Agree , 11\% I don't know, 5\% Disagree, 3\% Strongly disagree). Then most people indicate that psychoactive substances are not necessary, as evidenced by the results presented in the diagram below.

\section{Disscussion}

Addiction is an issue that is very often raised in psychological and medical literature, as well as in literature that is related to the media studies (Everitt, Robbins, 2016). An important issue of the conducted research is that the respondents pay attention to negative aspects related to addiction in various age groups, also during the midlife. At the same time, they recognize that when they are in the universities or high school may be related to the fact that people are looking for new impressions and experiences, sometimes using psychoactive substances to learn faster, improve your concentration and motivation to work. Undoubtedly, the psychoactive substances are usually used when a person wants to improve his/her mood or spend time with the people using some type of substance. (Knapik, 2011) Sometimes, the use of alcohol, legal highs, cigarettes, including electronic cigarettes is an opportunity to join a given social group. (Knapik, 2011)

Most respondents say that they monitor their behaviour or behaviour of family members or friends, and that allows them to intervene adequately in a difficult situation. At the same time, most pay attention to the fact that in the past, parents, friends or partner paid attention to the amount of alcohol or stimulants consumed. The influence of these people allowed for the appropriate dosage of the substance and no problems with addiction. (Donaldson, Handren, Crano, 2016) 
By responding to hypothesis 1, young adults declare that they have knowledge about e-drugs. However, this can be considered insufficient knowledge, as in many cases incorrect answers appeared on this topic, suggesting that the information obtained by the respondents is not checked and does not come from a scientific source.

In this study, e-drugs are treated as not harmful and not treated as hazardous comparing to such substances as alcohol, heroin, as well as gambling or computer games.

Interestingly, the results may be related to the fact that there are many preventive campaigns about alcohol, drugs or even cigarettes, information spots or documentary films that describe in detail the adverse effects on human health and life (Skara, Sussman, 2003) At school prevention is being carried out, and the consequences associated with the use of drugs or legal highs are presented in the media (Antkiewicz, 2014)

The juxtaposition of e-drugs with substances that appear more often in everyday life could lead to the fact that these substances are not considered serious.

An important issue is that even a dozen or so years ago, behavioural problems related to computer games were not as serious as they are at present, as evidenced by the growing number of studies on this subject (Dalal, Basu, 2016) Aspects related to gambling also represented not as big a problem as they do now (Gainsbury, 2015)

Hypothesis 2 was related to the fact that young people who use psychoactive substances can reach for other substances, including e-drugs. If, according to the assumption, e-drugs were not known to the subjects, they often reach for new possibilities. People who use psychoactive substances may try others. It is worrying that respondents are trying more and more new substances because they want to experience something new, and also want to break away from everyday worries and take care of their positive mood (Wingo, Nesil, Choi and Li, 2015)

From a prevention perspective, it is important that the vast majority of respondents realize that addiction in Polish society is a big problem. It means that participants can resist public pressure. For example, the consumption of certain substances, e.g. alcohol, is conditioned by traditions and culture in 
Poland (Wnuk, Purandare, Marcinkowski, 2013). Still, participants use these substances with caution.

Referring to hypotheses 3 and 4, it can be argued that young people perceive e-drugs as less hazardous than other psychoactive substances, while not being aware of the dangers of using e-drugs.

Due to the appropriate design of the survey, you can get more information on the perception of e-drugs. In the context of the fact that most respondents consider e-drugs to be less dangerous than others - most would like to experience the impact of these substances. Any situation of excessive consumption of psychoactive substances or undertaking a given activity can lead to many serious changes in the social and psychological aspects. (Fox, Govind, Ellis, 2013)

\section{CONCLUSIONS AND SUMMARY}

The 21st century is undoubtedly associated with the fast pace of work, the desire to get money, experience or prestige (Kwiatkowska, Siudem, 2011). Sometimes, the lack of time for sport, relaxation or rest can result in people reaching for substances that will artificially allow them to function. An access to e-drugs is a niche topic that also appears more and more often. (Tuszyńska-Bogucka, Kwiatkowski, 2015) Many people are constantly looking for various forms of increasing their productivity and intellectual ability. The problem is not a one-time reach for various sunstances, but an addiction, which in the future may have many negative effects on the life of an individual, family and society.

The study is a part of a series, which aims to increase knowledge about various substances that will appear more and more often due to the continuous development of civilizations. It is very important to pay attention to preventive measures. The practical implications that could be created in connection with the scientific research will be presented below.

Practical implications:

1. Prevention concerning psychoactive substances and the possibility of behavioral and mental addiction should be carried out from an early age.

2. No addiction should be treated as less dangerous than others. 
3. People addicted or with a tendency to addiction should be under specialist control: addiction expert, psychologist, psychiatrist.

4. There should be more and more tests for the presence of psychoactive substances in the body - carried out at schools, universities or at work to eliminate undesirable and harmful behavior.

5. A healthy lifestyle should be promoted in the media without the need for psychoactive substances.

6. More attention should be paid to addictions, which constitute an insignificant percentage, e.g. the use of e-drugs, addiction to pornography or compulsive shopping.

7. Psychoeducation is important. It should be related of the importance of taking care of one's own health and the health of the close ones.

8. Prevention should be carried out in the field of mental health, because in many aspects reaching for alcohol or other psychoactive substances may be associated with the desire to drown out your negative thoughts or improve your mood.

9. Information on drugs should be provided by professionals to reduce the occurrence of harmful behaviour and to prevent increasing the use of such substances.

10. Manufacturers of substances should put on their products information about all possible undesirable effects of using given substances or methods, and the lack of such information should be punished.

\section{Bibliography}

Antkiewicz B. (2014) Profilaktyka narkomanii w szkołach - zapobieganie, leczenie i reintegracja społeczna, Kontrola państwowa, 2(355), s. 132-144. ISSN 04525027.

Asad A. (2012) Can Digital Drugs Get You High? Pobrane z: https://www.vice.com/ en_us/article/gqw35q/i-tried-to-get-high-using-digital-drugs (29.01.2020)

Bhatia P., Rasal S., Shelar S. iMulik V. (2016) Binaural beats "amenable or not", International Journal of Current Research 8(8), s. 35960-35962. doi: https://doi. org/10.1515/ijamh.2012.041. ISSN 0975-833X.

Dalal P., Basu D. (2016). Twenty years of Internet addiction ... Quo Vadis?, Indian journal of psychiatry, 58(1), s. 6-11. ISSN 0019-5545. 
Donaldson C., Handren L., Crano W. (2016). The Enduring Impact of Parents' Monitoring, Warmth, Expectancies, and Alcohol Use on Their Children's Future Binge Drinking and Arrests: a Longitudinal Analysis, Prevention Science, 17, s. 606-614. ISSN 1389-4986.

Everitt B., Robbins T. (2016). Drug Addiction: Updating Actions to Habits to Compulsions Ten Years On, Annual Review of Psychology, 67, s. 23-50. ISSN 00664308.

Fawzi M., Mansouri F., (2017). Awareness on Digital Drugs Abuse and its Applied Prevention Among Healthcare Practitioners in KSA, Arab Journal of Forensic Sciences and Forensic Medicine, 1. doi: 10.26735/16586794.2017.002.

Fox T., Govind O., Ellis S. (2013). The Destructive Capacity of Drug Abuse: An Overview Exploring the Harmful Potential of Drug Abuse Both to the Individual and to Society, ISRN Addiction. 10.1155/2013/450348.

Gainsbury S. (2015). Online Gambling Addiction: the Relationship Between Internet Gambling and Disordered Gambling, Current Addiction Reports, 2, s. 185-193. ISSN 2196-2952.

Greydanus, D. \&Greydanus, M. (2012). Internet use, misuse, and addiction in adolescents: current issues and challenges, International Journal of Adolescent Medicine and Health 24(4), s. 283-289. ISSN 0334-0139.

Jarczyńska J., Orzechowska A. (2014). Siecioholizm i fonoholizm zagrożeniem współczesnej młodzieży. W: Jarczyńska J. (red), Uzależnienia behawioralne i zachowania problemowe młodzieży (s. 121-146). Bydgoszcz: Wydawnictwo Uniwersytetu Kazimierza Wielkiego. ISBN 9788380180017.

Knapik W. (2011). Przeobrażenia kulturowe na podstawie badań młodzieży studenckiej z Małopolski w zakresie narkomanii, Acta Universitatis Lodziensis. Folia Sociologica, 37, s. 187-205. ISSN 0208-600X.

Kwiatkowska G.E., Siudem A., (2011). Człowiek w Środowisku Pracy, Lublin: Wydawnictwo UMCS. ISBN 9788322732960.

Le Scouarnec R., Poirier R., Owens J., Gauthier J., Taylor A., Foresman P. (2001) Use of binaural beat tapes for treatment of anxiety: a pilot study of tape preference and outcomes, Alternative therapies in health and medicine, 7(1), s. 58-63. ISSN 1078-6791.

Mackey T., Liang B., Strathdee S. (2013) Digital Social Media, Youth, and Nonmedical Use of Prescription Drugs: The Need for Reform, Journal of Medical Internet Research, 15(7). doi: 10.2196/jmir.2464.

Motyka M. (2015). New methods of narcotization. Part VII. Digital drugs, Problemy Higieny i Epidemiologii, 96(2) s. 309-314. ISSN 1895-4316. 
Ozkan M., Solmaz B. (2015) Mobile Addiction of Generation Z and its Effects on their Social Lifes: (An Application among University Students in the 18-23 Age Group), Procedia - Social and Behavioral Sciences, 205, s. 92-98. ISSN 1877-0428.

Reedijk S., Bolders A., Hommel B. (2013) The impact of binaural beats on creativity, Frontiers in Human Neuroscience, 7. doi: 10.3389/fnhum.2013.00786.

Runcan R. (2015) Facebookmania - the psychical addiction to Facebook and its incidence on the Z generation, Revista de Asistenţă Socială, 3, s. 127-136. ISSN 1583-0608.

Sas C., Chopra R. (2015). MeditAid: a wearable adaptive neurofeedback-based system for training mindfulness state, Personal and Ubiquitous Computing 19, s. 1169-1182. ISSN 1617-4909.

Singh A. (2014) Challenges and Issues of Generation Z, IOSR Journal of Business and Management (IOSR-JBM), 16(7), s. 59-63. ISSN 1535-668X.

Skara S., Sussman S. (2003) A review of 25 long-term adolescent tobacco and other drug use prevention program evaluations, Preventive medicine, 37(5), s. 451-474. ISSN 0091-7435.

Stradomska, M. (2019). Uwarunkowania prób samobójczych w grupie studentów - program profilaktyczny prowadzony na uniwersytecie, Psychiatria i Psychologia Kliniczna, 19 (3), p. 293-307. ISSN 1644-6313.

Stradomska, M., Wolińska, J., Marczak, M. (2016). Circumstances and underlying causes of suicidal attempts in teen patients of mental health facilities - a psychological perspective, Psychiatria i Psychologia Kliniczna, 16(3), 136-149. ISSN 1644-6313.

Tuszyńska-Bogucka W., Kwiatkowski P. (2015) „Naćpani dźwiękiem”? E-narkotyki jako obszar badań przyszłości, Horyzonty Psychologii,5, s. 29-43. ISSN 2083-5248.

Wiszejko-Wierzbicka D., Kidawa M., Jabłońska M. (2016). Motives of new psychoactive substance use and typology of users based on survey and Internet forum analysis within the I-TREND project, Alcoholism and Drug Addiction, 29(2), s. 61-74. ISSN 0867-4361.

Wingo T., Nesil T., Choi J., Li M. (2015) Novelty Seeking and Drug Addiction in Humans and Animals: From Behavior to Molecules, Journal of Neuroimmune Pharmacology, 11, s. 456-470. ISSN 1557-1890.

Wnuk M., Purandare B., Marcinkowski J. (2013). Struktura spożycia alkoholu w Polsce w ujęciu historycznym, Problemy Higieny i Epidemiologii, 94(3), s. 446-450. ISSN 1895-4316.

LeonidovichI., EsakovV., NazarovaL. (2014) Audionarkotiki. Zvuk vmesto "khimii", Chelovek, Rossiyskaya akademiya nauk (Moskva), 3, s. 66-76. 
Leonovich E. (2014) Audionarkotiki (zvukovyye narkotiki). Chto eto? Pobrane z: https://sub-cult.ru/chtivo/statji/2279-audionarkotiki-zvukovye-narkotiki-chtoyeto (29.01.2020).

Pukhlykh L. (2009) Audionarkotiki: novyy vid opasnykh stimulyatorov rasprostranyayetsya cherez Internet, Argumenty i fakty. Pobrane z: https://aif.ru/health/ life/12258 (29.01.2020). 